\title{
The Effect of Tiller Transplanting Technique and Water Availability on the Growth and Yield of Sidaguri (Sida rhombifolia)
}

\author{
Dhimas Taufika Putra*, Bambang Pujiasmanto and Supriyono \\ Department of Agronomy, Post-Graduate Program of Universitas Sebelas Maret, Surakarta, Indonesia \\ *Corresponding author: dhimastaufika@student.uns.ac.id
}

\begin{abstract}
Sidaguri (Sida rhombifolia) is a wild plant with the ability to cure various diseases. Continuous exploitation of natural source can reduce the sustainability of this plant species. On the other hand, this plant is often ignored because it is considered as weed. This study aims to provide information about proper cultivation of Sidaguri to the community and medicinal plant farmers in order to maintain its sustainability and its potential to be used as cultivated plant. The study used a Completely Randomized Design (CRD) with two treatment factors: transplanting techniques (puteran, cabutan, stump) and water availability $(50,37.5,25,12.5 \%$ water field capacity). Observation data were analyzed by analysis of variance and followed by DMRT test at 5\% upon the significant result. The results have revealed that the transplanting technique of transplanting tillers with puteran technique produces the best growth and $25 \%$ water availability increases plant growth and yield. The result suggests that Sidaguri is a plant that is tolerant to drought.
\end{abstract}

Keywords: medicinal plant, transplanting, water availability

Cite this as: Putra, D. T., Pujiasmanto, B., \& Supriyono. (2019). The Effect of Tiller Transplanting Technique and Water Availability on the Growth and Yield of Sidaguri (Sida rhombifolia). Caraka Tani: Journal of Sustainable Agriculture, 34(2), 179-187. doi: http://dx.doi.org/10.20961/carakatani.v34i2.27186

\section{INTRODUCTION}

Sidaguri is a wild plant from the Malvaceace family which is well-known as a cure to various diseases, (Simarmata et al., 2013) one of which is gout. Sidaguri flowers are used to treat insect bites, their antibacterial leaves are used as a cure for itch, and their roots are used to treat rheumatic, asthma and influenza, and reduce pain in toothache (Tanumihardja et al., 2013) by biting them on the ail teeth or gargling with Sidaguri root boiled water (Natsir and Nurhayati, 2014). Some studies show that Sidaguri is very useful inhibiting the growth of the bacterium, such as Mycobacterium smegmatis at a dose of $10 \mathrm{mg}$ $\mathrm{mL}^{-1}$ (Sari, 2016) and Mycobacterium tuberculosis (Papitha et al., 2013). Sidaguri contains several secondary metabolites, including flavonoids rhombifolin (Fadilah, 2017) and alkaloids. Lenny and Barus (2010) in their research have proven that Sidaguri leaves contain alkaloid compounds. Information on the propagation method of Sidaguri is deficient because it is abundant in nature and even considered as non-economically potential for cultivation.

On the other hand, many people have not yet known the benefits of Sidaguri, so the plants are often ignored and considered as weeds growing on cultivated land. Therefore, it is necessary to immediately undertake cultivation efforts aimed at maintaining the existence of Sidaguri due to illegal and uncontrolled extraction and destruction of its natural habitat (Pujiasmanto, 2016). The initial stage of cultivating a plant is preparing planting materials, particularly tillers, either generative or vegetative ones. Generative tillers

\footnotetext{
* Received for publication January 22, 2019

Accepted after corrections June 21, 2019
} 
are obtained from the seeds. However, for plants that are difficult to reproduce generatively, tillers are taken from saplings around the parent plants in the wild. Transfer of tillers from nature can be done with some techniques, including puteran (taking the tillers with the soil around roots), cabutan (pulling-off the tillers immediately without the soil around roots) (Budiawan, 2009) and using stump.

East Java Forestry Agency (2013) explained that stump is part of roots and stems of a plant which is cut to be planted in the field. Stump only leaves the taproot and main stem and new roots will emerge, and this indicates adaptation and growth. Some plant cultivation practices in Indonesia are often constrained by the availability of water, especially due to climate change. Drought in some cases can cause hampered growth and decreased yield of plants. However, according to Ai (2011), drought stress does not always have a harmful impact if it can be detected at certain level of stress that can be tolerated. Gulen and Eris (2004) also stated that drought stress could be used to increase the secondary metabolic content of a plant. Drought stress on purwoceng affected the increase of active ingredients such as steroid, saponin and bergapten (Trisilawati and Pitono, 2015).

In soybean plants, water shortage conditions affect the final phase of pod development and mid-seed filling in drought stress treatment is $40 \%$ field capacity (FC) with Ultisol soil types (Nurhayati, 2009), but can increase proline content in the leave (Hasanah and Rahmawati, 2014). Proline is one of the secondary metabolites produced by plants in order to survive in drought conditions (Yusniawati et al., 2008). Drought stress in Indigofera zollingeriana contributes to the highest tanin and saponin in $25 \%$ FC of water availability (Herdiawan et al., 2014) and drought stress in tempuyung, $60 \% \mathrm{FC}$, contributes to doubled level of flavonoids, compared to the level of flavonoids of plants that are not affected by stress (Rahardjo and Darwati, 2017).

Abdillah et al. (2015) also said in the results of his research on Soghum and Purwati (2017) on Phyllanthus nururi and Phyllantus urinaria showed the availability of water in small amounts at the beginning of vegetative sorghum could increase the percentage of flavonoid content per phenolic. However, it must also be considered the accuracy of the period and the level of the stress so that there is no excessive reduction in biomass.
Decreasing excess biomass will cause plants lose balance in their metabolic processes and prolonged exposure to heat will be lethal. This study aims to provide information about the right cultivation method of Sidaguri to be applied by the community in preserving Sidaguri and marginal land use in an effort to support the implementation of sustainable agriculture.

\section{MATERIALS AND METHOD}

The field research was conducted in December 2016 to August 2017 at Donohudan Village, Ngemplak District, Boyolali Regency, Central Java. Laboratory research was carried out at the Ecology and Plant Production Management Laboratory, Faculty of Agriculture, Universitas Sebelas Maret (UNS), Soil Physics Laboratory of Faculty of Agriculture, Soil Chemical Laboratory of Faculty of Agriculture and the Chemistry Laboratory of Mathematics and Natural Science Faculty of Universitas Gadjah Mada (UGM).

Sidaguri tillers are obtained from their natural habitat at the Cepogo District, Boyolali Regency, which has an altitude of about 800 meter above sea level and the average temperature of $23^{\circ} \mathrm{C}$ and is dominated by regosol soil. Plants with multiple age levels are found in these habitats. This study used a uniformed source which has 5 leaves or a height of $5 \mathrm{~cm}$ of the tillers. Based on the results of soil chemical analysis, the chemical properties of the regosol soil taken are classified as poor, as indicated by the low number of $\mathrm{N}, \mathrm{K}$ and organic matter content. The plastic houses were established in Donohudan Village, Ngemplak Subdistrict, Boyolali and placed in the middle of rice fields to minimize any shade so that the sunlight intensity was obtained optimally throughout the day.

The temperature in a plastic house was $56^{\circ} \mathrm{C}$ during the day and $23^{\circ} \mathrm{C}$ at night. Maintenance was carried out every day for eight months until harvest and water availability treatment was carried out in two months before harvest. The equipment included tools for tillage, planting, maintenance, observation and analysis of secondary metabolites content (hoes, shovels, polybags, scissors, rulers, ballpoint pens, thermometers, balts, etc.). The media and planting materials were Sidaguri plants, tillers and chemicals for the analysis of secondary metabolites. 
The study used a Completely Randomized Design (CRD) consisting of two treatment factors with three replications in each treatment. The first factor is the tiller transplanting technique, consisting of three types, namely puteran, cabutan and stump techniques. The second factor was water availability, categorized into four levels of water conditions, namely 50, 37.5, 25 and $12.5 \%$ FC. Data were analyzed using variance analysis and the analysis was followed by DMRT (Duncan Multiple Range Test) 5\% when the results were significantly different.

The growth parameters observed included plant height (measured by a ruler), number of leaves (calculated manually) and number of branches (calculated manually), while the yield parameters included root length (measured by a ruler), fresh root weight (measured by a scale) and secondary metabolite content of flavonoids. Plant height measurements were carried out by measuring plants from the base of the stem to the highest end of the leaf using a ruler.

Calculation of the number of leaves was done by counting the number of leaves at full bloom and done at intervals of four weeks. Calculation of the number of branches was completed by counting all branches, either primary or secondary branches, of a plant. The measurement of root length was conducted after the plants were harvested by measuring the longest roots from the base to the farthest end of the root, carried out after harvest. The fresh weight calculation of the roots was done by taking the roots, washing them to remove the remaining soil and then weighing them using a digital analytic scale. Calculation of secondary metabolite content in the form of flavonoids contained in plant roots was carried out by Spectrophotometry UV-Sis method.

Land preparation included land clearing activities that are used to lay polybags from weeds and other plant remnants. After that, a $10 \mathrm{~m} \times 8 \mathrm{~m}$ greenhouse was built. The media used were native regosol where the sidaguri seeds were taken with the intention that there was no difference in soil type for each treatment in this study. The soil was filtered with a small wire mesh filter so that the texture was the same, and then put in each polybag measuring $50 \mathrm{~cm} \times 50 \mathrm{~cm}$ according to the previous arrangement. In this stage, the FC measurement was also carried out for drought stress treatment. The planting materials used were sidaguri tillers, having the same age and originating from the same place, Cepogo,
Boyolali Regency. The sidaguri seeds were planted in $50 \mathrm{~cm} \times 50 \mathrm{~cm}$ polybags filled with soil, particularly in 7-10 $\mathrm{cm}$ depth.

Before sidaguri plants were given drought stress treatment, they were watered with sufficient clean water every afternoon. After the plants were given drought stress treatment, watering was done according to the calculation of the FC. Weeding was carried out by cleaning weeds around polybags and planting field and manually by removing weeds that grow, adjusting the conditions of the field. Pest was controlled manually, namely by taking pests that attack plants and controlling the disease using natural methods.

The treatment of water availability was given from the beginning of planting to harvest, including giving water $50,37.5,25$ and $12.5 \%$ of FC, carried out according to the calculations which were then maintained in these conditions every two days. Observations on plant height, number of leaves and number of branches were carried out every four weeks. Observations on plant fresh weight, plant dry weight, root fresh weight, root length and content analysis of secondary metabolites (flavonoids) were carried out after harvesting. Sidaguri harvest started when the flowers appeared or when the plants were around four months of age, but in this study, it was carried out at the age of eight months according to the information from interview. Sidaguri plants were harvested by dismantling the entire roots using a spark and then cleaning the soil attached to the root.

\section{RESULTS AND DISCUSSION}

\section{Plant growth \\ Plant height}

Transplanting technique has significant effect on plant height, but water availability level does not have any significant effect on plant height and there is not any significant interaction between those two treatments (Table 1). The effects of tiller transplanting technique on plant height are presented in Table 2. Based on data analysis, transplanting of tillers with puteran technique produced the highest plant height.

\section{Number of leaves}

Tiller transplanting technique and water availability levels does not have any significant effect on the average number of Sidaguri leaves 
and there is not any significant interaction

between those treatments (Table 1).

Table 1. Analysis of variance the plant height, number of leaves, number of branches, root length, fresh root weight and total flavonoid content

\begin{tabular}{lccccccc}
\hline & & \multicolumn{6}{c}{ Probability of statistical significance level } \\
\cline { 3 - 8 } Source of variance & Df & $\begin{array}{c}\text { Plant } \\
\text { height }\end{array}$ & $\begin{array}{c}\text { Number } \\
\text { of } \\
\text { leaves }\end{array}$ & $\begin{array}{c}\text { Number of } \\
\text { branches }\end{array}$ & $\begin{array}{c}\text { Root } \\
\text { length }\end{array}$ & $\begin{array}{c}\text { Fresh } \\
\text { root } \\
\text { weight }\end{array}$ & $\begin{array}{c}\text { Total } \\
\text { flavonoid } \\
\text { content }\end{array}$ \\
\hline Transplanting technique & 2 & $*$ & $\mathrm{~ns}$ & $\mathrm{~ns}$ & $\mathrm{~ns}$ & $\mathrm{~ns}$ & $\mathrm{~ns}$ \\
Water availability & 3 & $\mathrm{~ns}$ & $\mathrm{~ns}$ & $*$ & $*$ & $*$ & $\mathrm{~ns}$ \\
Transplanting technique $\mathrm{x}$ & 6 & $\mathrm{~ns}$ & $\mathrm{~ns}$ & $\mathrm{~ns}$ & $\mathrm{~ns}$ & $*$ & $\mathrm{~ns}$
\end{tabular}

water availability

Note: $*$ = significant at $\mathrm{P}<0.05$ level; $* *=$ significant at $\mathrm{P}<0.01$ level, $\mathrm{ns}=$ not significant $(\mathrm{P}<0.05)$; $\mathrm{df}=\mathrm{degrees}$ of freedom

\section{Number of branches}

Water availability levels significantly affect the number of branches, but transplanting technique does not have any effect on it. Those two treatments does not have any interaction (Table 1). The effect of further treatment of water availability levels on the average number of branches are presented in Table 3 .

Table 2. The effect of tiller transplanting techniques on the average height of Sidaguri plants

\begin{tabular}{cc}
\hline $\begin{array}{c}\text { Tiller transplanting } \\
\text { technique }\end{array}$ & $\begin{array}{c}\text { Plant height } \\
(\mathrm{cm})\end{array}$ \\
\hline Puteran & $63.54^{\mathrm{b}}$ \\
Cabutan & $62.08^{\mathrm{b}}$ \\
Stump & $47.00^{\mathrm{a}}$ \\
\hline
\end{tabular}

Note: Numbers that are followed by the same letters in the same column are not significantly different at the $5 \%$ level of significance in DMRT test.

Sidaguri which is planted with the puteran technique produces the best growth result, characterized by plant height (Table 2), while $25 \%$ water availability can increase growth, indicated by relatively high number of branches (Table 3 ) and the best crop yield, indicated by high root length (Table 4) and root fresh weight (Table 4). Tillers planted with puteran techniques can continue to grow after being transplanted because the growth is not disturbed by the regeneration of wounds due to physical damage of roots and stems when removed or made into stumps. Root damage results in stunting plant growth (Yahya and Manurung, 2002) and plants returns to normal when they have found suitable environments to grow (Yahya and Manurung, 2002). Dainy (2006) also explained that plants which are not pruned will grow better because the growth is disturbed by the wound healing process.

Table 3. The effect of water availability level on the average number of Sidaguri branches

\begin{tabular}{cc}
\hline $\begin{array}{c}\text { Water availability } \\
\text { level }\end{array}$ & $\begin{array}{c}\text { Average number of } \\
\text { branches }\end{array}$ \\
\hline $50.0 \% \mathrm{FC}$ & $41.56^{\mathrm{a}}$ \\
$37.5 \% \mathrm{FC}$ & $76.38^{\mathrm{b}}$ \\
$25.0 \% \mathrm{FC}$ & $79.50^{\mathrm{b}}$ \\
$12.5 \% \mathrm{FC}$ & $79.93^{\mathrm{b}}$ \\
\hline
\end{tabular}

Note: Numbers that are followed by the same letters in the same column are not significantly different at the 5\% level of significance in DMRT test.

In addition to plant height, the number of leaves in this study is not highly affected by the tiller transplanting technique. It shows that one of the responses of plants toward drought is their activity of reducing the amount of transpiration Bouman and Tuong (2001) by rolling, reducing the area and aborting the leaves. The results of study by Hidayati et al. (2017) on mastwood plants also showed a significant decrease in the number of leaves after experiencing drought stress. Research on black locust (Anggraini et al., 2016) has revealed that plant height is lower when a plant is planted in least water availability.

Drought stress reduces the average number of leaves and affects the number of branches of plant. Sidaguri response to drought stress accelerates its life cycle, which is to increase flower growth through branches or twigs. Davenport (2003) revealed that in tropical regions 
that have erratic temperature fluctuations in each season, the flowering process occurs due to drought stress. Ramírez et al. (2014) also stated that drought stress can trigger flowering induction shortly after the shoot initiation. According to Solikin (2013), in plant morphology, flower bud grows on tip of branches or twigs. The number of branches also influences the number of flowers. The results of the study of Aji and Susanto (2010) stated that the number of branches significantly affects the number of flowers of Roselle plants (Hibiscus sabdariffa).

\section{Plant yield}

\section{Root length}

Transplanting technique does not contribute to the root length of Sidaguri, but water availability level significantly effects the root length. Those two factors do not have any significant interaction (Table 1). The effects of water availability on root length are presented in Table 4. Based on data analysis, $25 \% \mathrm{FC}$ of water availability produces the longer root length.

\section{Fresh root weight}

Transplanting technique no significantly effect to the fresh root weight of Sidaguri, but water availability levels significant effect and between those treatments had a significantly interaction (Table 1). The effects of water availability on fresh root weight are presented in Table 4. Based on data analysis, $25 \%$ FC of water availability produced the higher fresh root weight.
Table 4. The effect of water availability level on the average length and fresh weight of the Sidaguri root

\begin{tabular}{ccc}
\hline $\begin{array}{c}\text { Water } \\
\text { availability } \\
\text { level }\end{array}$ & $\begin{array}{c}\text { Average } \\
\text { root length } \\
(\mathrm{cm})\end{array}$ & $\begin{array}{c}\text { Average fresh } \\
\text { root weight } \\
(\text { gram) }\end{array}$ \\
\hline $50.0 \% \mathrm{FC}$ & $51.88^{\mathrm{a}}$ & $8.36^{\mathrm{a}}$ \\
$37.5 \% \mathrm{FC}$ & $59.44^{\mathrm{ab}}$ & $12.76^{\mathrm{ab}}$ \\
$25.0 \% \mathrm{FC}$ & $77.00^{\mathrm{b}}$ & $14.78^{\mathrm{b}}$ \\
$12.5 \% \mathrm{FC}$ & $69.61^{\mathrm{ab}}$ & $11.71^{\mathrm{ab}}$ \\
\hline
\end{tabular}

Note: Numbers that are followed by the same letters in the same column are not significantly different at the 5\% level of significance in DMRT test.

\section{Total flavonoid content}

Tiller transplanting technique and water availability levels does not significantly put effect on the average flavonoid content and there is not any significant interaction between those factors (Table 1). The effect of water availability is seen not only in plant growth, but also in the yield. In general, Sidaguri plants secondary metabolite contents are extracted from the leaves or roots as a result of their cultivation depending on their needs. But in this study, roots are the main yields used. The treatment of water availability is seen to increase crop yields, concluding from the average root length and fresh weight of roots. Plants that get water availability to a certain extent will extend their roots to get water as an adaptation.

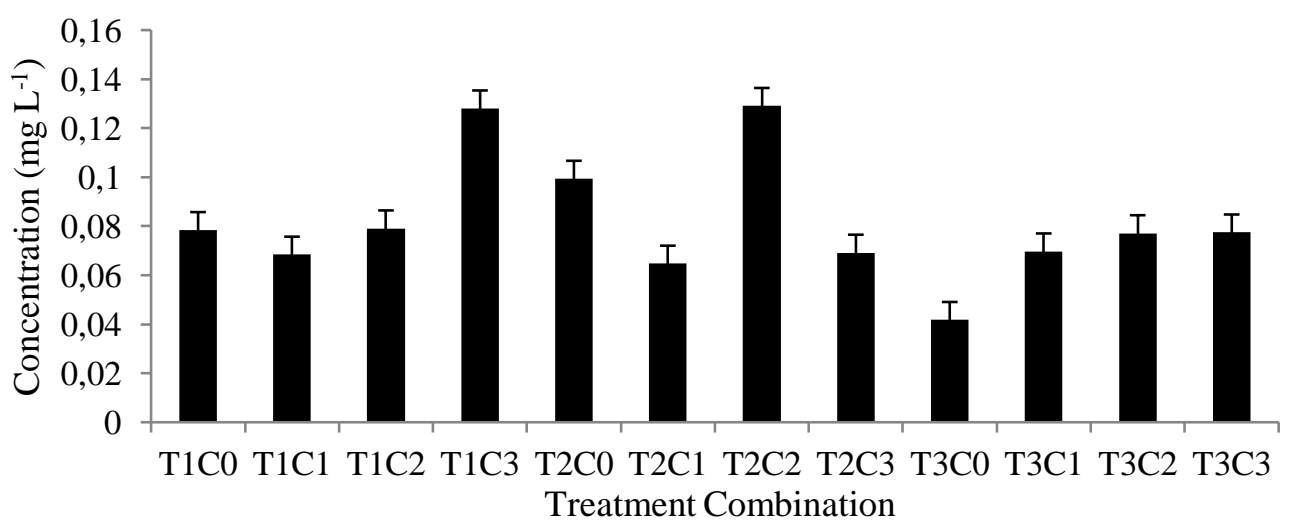

Figure 1. Histogram of the average total flavonoid content in each treatment combination

Note: $\mathrm{T} 1=$ puteran technique; $\mathrm{T} 2=$ cabutan technique; $\mathrm{T} 3=$ stump technique; $\mathrm{C} 0=$ water availability with $50 \% \mathrm{FC} ; \mathrm{C} 1=$ water availability with $37.5 \% \mathrm{FC} ; \mathrm{C} 2=$ water availability with $25 \% \mathrm{FC} ; \mathrm{C} 3$ $=$ water availability with $12.5 \% \mathrm{FC}$

Palupi and Dedywiryanto (2008) explained that plants with longer roots could absorb water better. Zlatev and Lidon (2012) also explains that the higher allocation for root biomass aims to increase the capacity of water taken by roots. Djazuli (2010), conducting research on sweet 
potatoes, also mentioned that during long dry season, sweet potato roots are able to extend their roots to $2 \mathrm{~m}$. Fresh root weight is closely related to root length and volume. The average longest roots in this study are the roots of plants with water availability of $25 \% \mathrm{FC}$.

The results of the correlation test between root length and fresh root weight indicate a positive correlation, i.e. when the roots are longer, they will be heavier. Febriyono et al. (2017) in his study of water spinach also mentioned that plants that get the lowest water and nutrient conditions will extend and spread their roots, affecting the fresh weight of the roots. The average histogram of total flavonoid content indicates that the stress up to $12.5 \%$ of FC produces high flavonoids content compared to plants that are given stress with lower levels (50\% and 37.5\% FC) (Figure 1). This shows that Sidaguri is a plant with a high tolerance to water availability because of its ability to produce high flavonoids in much stressed conditions.

Several studies have proven its role in sustaining life against drought stress (Vicente and Boscaiu, 2017), as shown in Arabidopsis thaliana (Nakabayashi et al., 2014). Hernández et al. (2004) added in the results of his study that the levels of flavonoids in plant plants Clusii cistus increase in drought conditions due to high temperatures and low rainfall in the Mediterranean climate.

Plant height, number of leaves, number of branches, fresh weight roots and root length have a positive correlation with each other. Leaf is an important part of plants that produce photosynthates for the growth of all plant organs. In stump technique, transplanting is done by removing the leaves, so that it reduces the number of leaves and the other organs. In puteran technique, plants do not experience obstructions to grow when transplanting process is done, meaning that the leaves will continue to grow and produce enough photosynthates to be distributed to other growing organs. After the treatment of limiting the water availability is given, branches are mostly visible at $25 \% \mathrm{FC}$ and the plants produce fresh weight of roots and root length under the highest stress. Environmental conditions with low water availability cause plants to increase the number of branches to complete their life cycle immediately and extend the roots to be able to absorb more water, thus increasing the fresh weight of the roots. The content of flavonoids has a negative correlation. The correlation with other variables is very weak.

\section{CONCLUSIONS}

Tiller transplanting technique only affects the plant growth (the best growth obtained by puteran technique), while the presence of water availability can influence the growth and yield of Sidaguri. Available water of $25 \%$ and $12.5 \%$ of FC result in best Sidaguri yield in the form of root length, root fresh weight and flavonoid content.

\section{ACKNOWLEDGMENTS}

The author would like to thank Mr Suratno (Cepogo) for his assistance providing the Sidaguri tillers, and the Sringanis Cipaku (Bogor) Herbal Garden for very detailed information about the Sidaguri.

\section{REFERENCES}

Abdillah, D., Soedradjad, R., \& Siswoyo, T. A. (2015). Pengaruh Cekaman Kekeringan terhadap Kandungan Fenolik dan Antioksidan Tanaman Sorgum (Sorghum bicolor L. Moench) pada Fase Awal Vegetatif. Retrieved from http://repository.unej.ac.id/handle/1234 56789/70557

Ai, N. S. (2011). Biomassa dan Kandungan Klorofil Total Daun Jahe (Zingiber officinale L.) yang Mengalami Cekaman Kekeringan. JURNAL ILMIAH SAINS, 11(1), 1-5. https: //doi.org/10.1234/JIS.V11I1.31

Aji, T. G., \& Susanto, S. (2010). Pengaruh Jumlah Cabang terhadap Pertumbuhan Vegetatif dan Generatif Rosela (Hibiscus sabdariffa L.) (IPB (Bogor Agricultural University)). Retrieved from https:// repository.ipb.ac.id/handle/123456789/36262

Anggraini, N., Faridah, E., \& Indrioko, S. (2016). Pengaruh Cekaman Kekeringan terhadap Perilaku Fisiologis dan Pertumbuhan Bibit Black Locust (Robinia pseudoacacia). Jurnal Ilmu Kehutanan, 9(1), 40. https://doi.org/ 10.22146/jik.10183

Bouman, B. A., \& Tuong, T. (2001). Field water management to save water and increase its productivity in irrigated lowland rice. Agricultural Water Management, 49(1), 1130. https://doi.org/10.1016/S0378-3774(00)00 
$128-1$

Budiawan. (2009). TECHNICAL REPORT MANUAL PELATIHAN: Teknik Persemaian dan Silvikultur (Volume 3; Bambang Hendiarto, Ed.). Retrieved from https://www. scribd.com/document/318371129/VOLUME3-TECHNICAL-REPORT-MANUALPELATIHAN-pdf

Dainy, N. C. (2006). Produksi Kandungan Flavonoid Daun Sambung Nyawa (Gynura procumbens [Lour]. Merr) pada Berbagai Tingkat Naungan dan Umur Pemangkasan. Retrieved from https://repository.ipb.ac.id/ handle/123456789/1530

Davenport, T. (2003). Management of Flowering in Three Tropical And Subtropical Fruit Tree Species (pp. 1331-1335). pp. 1331-1335. Retrieved from https://pdfs.semanticscholar. org/dea0/43c764174440069eead1fefb8af8ea5 87a99.pdf

Djazuli, M., \& Djazuli, M. (2010). Pengaruh Cekaman Kekeringan terhadap Pertumbuhan dan beberapa Karakter Morfo-Fisiologis Tanaman Nilam. Buletin Penelitian Tanaman Rempah Dan Obat, 21(01), 8-17. Retrieved from http://ejurnal.litbang.pertanian.go.id/ind ex.php/bultro/article/view/1864

East Java Forestry Agency. (2013). Budidaya Jati (Tectona grandis) dengan Benih/Bibit Berkualitas/Bersertifikat. Retrieved from http ://upt-pth.dishut.jatimprov.go.id/publish_file/ leaflet_budidaya_jati.pdf

Fadilah, N. N. (2017). Aktivitas, Mekanisme Aksi, dan Toksisitas Sidaguri (Sida rhombifolia L.) sebagai Antihiperurisemia. Farmaka, 15(2), 23-32. Retrieved from http:// jurnal.unpad.ac.id/farmaka/article/view/12414

Febriyono, R., Susilowati, Y. E., \& Suprapto, A. (2017). Peningkatan Hasil Tanaman Kangkung Darat (Ipomoea reptans, L.) melalui Perlakuan Jarak Tanam dan Jumlah Tanaman Per Lubang. Vigor: Jurnal Ilmu Pertanian Tropika dan Subtropika (Journal of Tropical and Subtropical Agricultural Sciences), 2(1), 22-27. Retrieved from http:// jurnal.untidar.ac.id/index.php/vigor/article/vie $\mathrm{w} / 323$

Gulen, H., \& Eris, A. (2004). Effect of heat stress on peroxidase activity and total protein content in strawberry plants. Plant Science, 166(3), 739-744. https://doi.org/10.1016/J.PLANTSC I.2003.11.014

Hasanah, Y., \& Rahmawati, N. (2014). Produksi dan Fisiologi Kedelai pada Kondisi Cekaman Kekeringan dengan Aplikasi Bradyrhizobium japonicum yang Diberi Penginduksi Genistein. Jurnal Agronomi Indonesia (Indonesian Journal of Agronomy), 42(2), 110 - 117. Retrieved from https://journal.ipb.ac.id/index. php/jurnalagronomi/article/view/8427

Herdiawan, I., Abdullah, L., \& Sopandi, D. (2014). Status nutrisi hijauan Indigofera zollingeriana pada berbagai taraf perlakuan stres kekeringan dan interval pemangkasan. Jurnal Ilmu Ternak Dan Veteriner, 19(2). Retrieved from http://medpub.litbang.perta nian.go.id/index.php/jitv/article/view/1037/10 57

Hernández, I., Alegre, L., \& Munné-Bosch, S. (2004). Drought-induced changes in flavonoids and other low molecular weight antioxidants in Cistus clusii grown under Mediterranean field conditions. Tree Physiology, 24(11), 1303-1311. Retrieved from http://www.ncbi.nlm.nih.gov/pubmed/15 339740

Hidayati, N., Laksmi Hendrati, R., Triani, A., \& Sudjino, S. (2017). Pengaruh Kekeringan terhadap Pertumbuhan dan Perkembangan Tanaman Nyamplung (Callophylum inophyllum L.) dan Johar (Cassia florida Vahl.) dari Provenan yang Berbeda. Jurnal Pemuliaan Tanaman Hutan, 11(2), 99-111. https://doi.org/10.20886/jpth.2017.11.2.99111

Purwati, I. (2017). Respon Pertumbuhan Dan Kandungan Flavonoid Pada Phyllanthus Niruri Dan Phyllanthus Urinaria Dengan Cekaman Kekeringan (UIN Sunan Kalijaga). Retrieved from http://digilib.uin-suka.ac.id/ 28652/

Lenny, S., Barus, T., \& Sitopu, E. Y. (2010). Isolasi Senyawa Alkaloid dari Daun SIdaguri (Sida rhombifolia L.). Jurnal Kimia Mulawarman, 8(1), 40-43. Retrieved from http://jurnal.kimia.fmipa.unmul.ac.id/index.ph $\mathrm{p} / \mathrm{JKM} /$ article/view/81

Nakabayashi, R., Yonekura-Sakakibara, K., 
Urano, K., Suzuki, M., Yamada, Y., Nishizawa, T., ... Saito, K. (2014). Enhancement of oxidative and drought tolerance in Arabidopsis by overaccumulation of antioxidant flavonoids. The Plant Journal : For Cell and Molecular Biology, 77(3), 367379. https://doi.org/10.1111/tpj.12388

Natsir, N., \& Nurhayati. (2014). Pemanfaatan Akar Sidaguri (Sida rhombifolia) sebagai bahan Analgetik. Retrieved from http:// repository.unhas.ac.id/handle/123456789/952 7

Nurhayati, N. (2009). Pengaruh Cekaman Air pada Dua Jenis Tanah terhadap Pertumbuhan dan Hasil Kedelai (Glycine max (L.) Merril). Jurnal Floratek, 4(1), 55-64. Retrieved from http://www.jurnal.unsyiah.ac.id/floratek/articl e/view/190

Palupi, E. R., \& Dedywiryanto, Y. (2008). Kajian Karakter Ketahanan terhadap Cekaman Kekeringan pada Beberapa Genotipe Bibit Kelapa Sawit (Elaeis guineensis Jacq.). Jurnal Agronomi Indonesia (Indonesian Journal of Agronomy), 36(1), 24-32. Retrieved from http://journal.ipb.ac.id/index.php/jurnalagrono $\mathrm{mi} /$ article/view/1341

Papitha N., Jayshree N., Seenivasan, S. P., \& Kumar, V. (2013). Anti-tubercular activityon leaves and roots of Sida rhombifolia L. International Journal of Pharmaceutical Sciences Review and Research, 23, 135-137. Retrieved from http://globalresearchonline. net/journalcontents/v20-2/23.pdf

Pujiasmanto, B. (2016). Strategi Pengembangan Budidaya Tumbuhan Obat dalam Menunjang Pertanian Berkelanjutan - Sebelas Maret University Library. Retrieved from https://library.uns.ac.id/strategi-pengemba ngan-budidaya-tumbuhan-obat-dalammenunjang-pertanian-berkelanjutan/

Rahardjo, M., Rahardjo, M., \& Darwati, I. (2017). Pengaruh Cekaman Air terhadap Produksi Dan Mutu Simplisia Tempuyung (Sonchus arvensis L.). Jurnal Penelitian Tanaman Industri (Industrial Crops Research Journal), 6(3), 7379. https://doi.org/10.21082/littri.v6n3.2000. 73-79

Ramírez, F., Davenport, T. L., Fischer, G., Pinzón, J. C. A., \& Ulrichs, C. (2014). Mango trees have no distinct phenology: The case of mangoes in the tropics. Scientia Horticulturae, 168, 258-266. https://doi.org/10.1016/J.SCI ENTA.2014.01.040

Sari, M. (2016). Evaluasi aktivitas anti miko bakterium tanaman obat Indonesia dengan pengujian reduksi resazurin. Seminar of Nasional Masyarakat Biodiversitas Indonesia Proceeding, 138142. https://doi.org/10.13057/ psnmbi/m020203

Simarmata, Y. B. C., Saragih, A., \& Bahri, S. (2013). Efek Hipourikemia Ekstrak Daun Sidaguri (Sida Rhombifolia L) Pada Mencit Jantan. Journal of Pharmaceutics and Pharmacology, 1(1), 21-28. Retrieved from https://jurnal.usu.ac.id/jpp/article/view/1962

Solikin, S. (2013). Pertumbuhan Vegetatif dan Generatif Stachytarpeta jamaicensis (L.) Vahl. Proceeding Biology Education Conference: Biology, Science, Enviromental, and Learning, 10(1). Retrieved from https://jurnal.uns.ac.id/ prosbi/article/view/6382

Tanumihardja, M., Darmayana, D., Natsir, N., \& Mattulada, I. K. (2013). Aktivitas antibakteri ekstrak terstandar akar sidaguri $(S$. rhombifolia) terhadap E. faecalis dan Actinomyces spp. Antibacterial activity of standardized extract of sidaguri root $(S$. rhombifolia) against E. faecalis and Actinomyces spp. Journal of Dentomaxillo facial Science, 12(2), 90-94. https://doi.org/ $10.15562 /$ jdmfs.v12i2.357

Trisilawati, O., \& Pitono, J. (2015). Pengaruh Cekaman Defisit Air terhadap Pembentukan Bahan Aktif pada Purwoceng. Buletin Penelitian Tanaman Rempah Dan Obat, 23(1), 34-47. Retrieved from http://ejurnal.litbang. pertanian.go.id/index.php/bultro/article/view/ $1830 / 5627$

Vicente, O., \& Boscaiu, M. (2017). Flavonoids: Antioxidant Compounds for Plant Defence... and for a Healthy Human Diet. Notulae Botanicae Horti Agrobotanici Cluj-Napoca, 46(1), 14-21. https://doi.org/10.15835/nbha 46110992

Yahya, S., \& Manurung, A. (2002). Kejut Tanam Cara Pindah Cabutan pada Pembibitan Kelapa Sawit. Jurnal Agronomi Indonesia (Indonesian Journal of Agronomy), 30(1), 12- 
20. Retrieved from http://journal.ipb.ac.id/ index.php/jurnalagronomi/article/view/1423

Yusniawati, Sudarsono, Aswidinnor, H., Hendrastuti, \& Santoso, D. (2008). Pengaruh Cekaman Kekeringan Terhadap Pertumbuhan, Hasil, dan Kandungan Prolina Daun Cabai. Jurnal Agrista, 12(1), 19-27. Retrieved from http://www.jurnal.unsyiah.ac.id/agrista/article

\section{/view/1147}

Zlatev, Z., \& Lidon, F. C. (2012). An Overview on Drought Induced Changes in Plant Growth, Water Relationsand Photosynthesis. Emirates Journal of Food and Agriculture, 24(1), 57. https://doi.org/10.9755/ejfa.v24i1.10599 